\title{
Kabul-City of Light
}

\section{PROJECT DESCRIPTION}

1. Information on the author of the project

Name:
Adr. Hisham N. Ashkourn, AlA
1185 Washington Street, West Newron, Massachusents 02465, USA

2. Deseription of the project

Project Tithe: City of Light, Kabul, Alghanistan

(c)

Sile: The project site is representec by the area south of the Kabul River within the limits of the City of Kabul. Its tength is $3.5 \mathrm{~km}$ and width $1.75 \mathrm{~km}$. The site is characterized by the extensive demofition that has resulted from several wars going back to the Soviel invasion all the way to the Talitban regitme. Yet, commercial and retali activity at this area is still alive and well. Also many collapsed st

Chert: The chient is the private sector parthering with the Naflional Government of Aghanistan.

Staths of Devefopment: An agreerment was signed with the Covemment of Afghanistan to develop his project The project design concept is being presented to M. Hamid Karai and appropriate

Textual Description (2.800 characters):

The develogment was conceived after visiting Kabut in September 2004. The openness and tove shown by the Aghan people was the most enightening expenence. and the Ciny of $L$ gat

A building envelope, imaginary plane, was developed creating vaning heights based on land-use and zoning requirements. An engineering grid was laid out over the area of development based on infrastructure needs and ground condritions. The grid was then projected through the imagiriary plane creating the massing for the entire urtan development this massing included retai, cornm

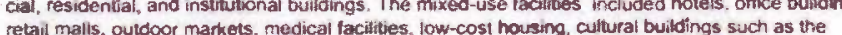
Nationai Nuseum of Afghan Hentage, open ais amphisheaters and movies theaters, public parks and pedestrian malis, fountains, new roadways. parking and public transit system. The deveropment would be set up simiarty to the new plan of Dubai where various land packages can be publicly b with the national government providing the infrastructure services

3. Five to ten hnages (drawings) illustrating the project: See drawings 1 through 9

4. Photo of Design Team: See design team photo and names in this drawing.

5. Statement about project's retations to the five target areas:

- Quanfum Change and Transferability:

The design of the Cay of Lignt is based on "Anio Region Design Techniqua" that has proven issell over the past decades on smali scale buldings in cities such as Istanbul, Baghdad, Istahant, and Kabu

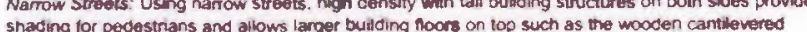
rooms or Mastrabias lound in Cairo. Please roter to dramings 4 and 5

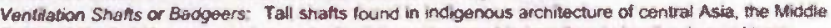
East and North Afrce was used as part of bullding skins provided cooling duning the day and head

Cily ol Light Design Concept Our design uses the narrow street high density and the Badgee concept in a new application of tall high-nise buildings reaching 35 stones. This concepl repre. sents quantum change in designing for ard regions, not mimicking other cites, based on prove
building practices. We project that such a design concept can be applied with some changes to many other developing cities in hot arid regions in Asia, the Middie East and North Africa.

b. Ethicar Siandards and Sociai Equity

The Ciry of Light Develooment represents new economic opportunity for the people of and after occupancy of the new buldings. The developmert will include the first notion museum of Afghan Heritage, national ftrary and cultural center and a new engineering school to be localed in Necklace Park

The purchase of tand for development will atso result in about $50 \%$ reduction of cost of towthcome housing, In addition $10 \%$ of profit will be set aside for seed money ic encourage refurtishtrment of nearby homes and businesses.

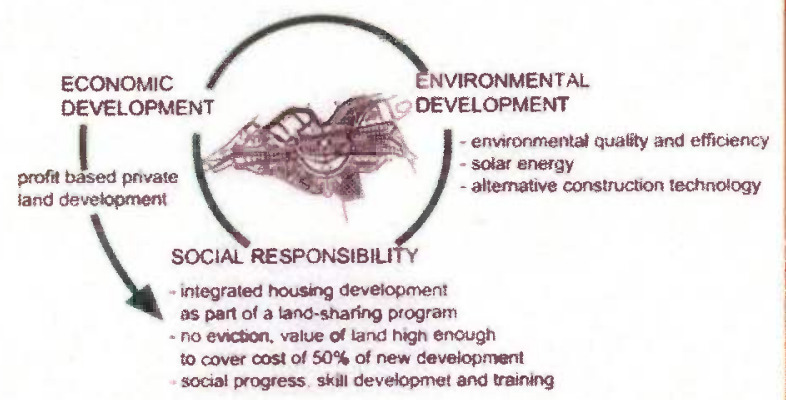

c- Ecological qualihies and energy conservation:

The project will be based on extensive use of concrete, in all hightrise and national structures inciucting all exterior solar screen work. in addition the design will use brick. glass and other local or recycled materials that are abundant in Afgnanistan. The design will employ higher archilectural density and ventialed facades, to cut cooling energy cycle costing, maintenance and long term environmental responsibility.

\section{acenomic performance and compalibility:}

The profect is being backed by several investment firms, US Government agencies and ine Afghan Govemment. The Cily of Light is being presented on Aparl 10.12, 2005 to the Abu Dhabi Government (mww. abudhabicityplan. com). The profect has aiso project aiso recognizes the economic scale and locat construction costs in A Aghanistan and that the budget and time set up for this project reffect this fact Project cust: $\$ 9$ billion, duration 20 years.

- Contextual response to sesthetic impact:

The bases of aesulhetc response are rooted in the nich history of Aghan jewelry and rug designs. the buildings assembled in this project are most adaptabte to various design themes especially with the extonor glass skin berng sef within an outside screen of cotored concrete in the shape of women's jewery and rug pattems. The designs will be extrapolated from aighan mages providing posituve suppon of loca spint and future in the most beativis wasing concrete as the new conted

\section{Self assessment:}

Based on the response to the five target issues, we believe that our project is on its way to accomplishing all the goals listed. We have long way to go and we need to

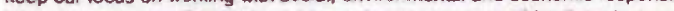
We rate our accomplishments

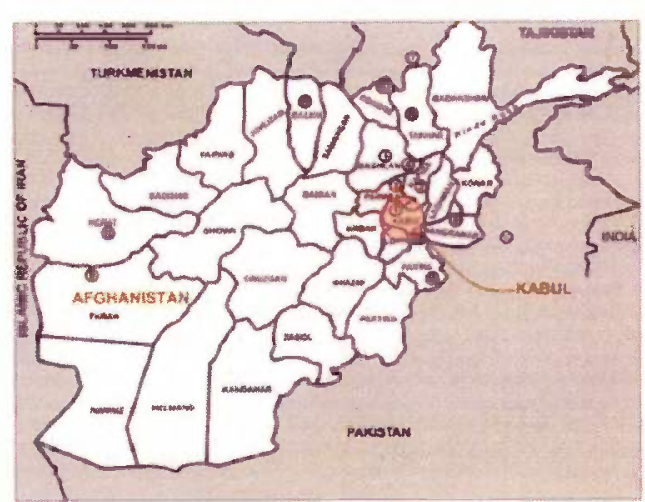

\section{COUNTRYIREGION}

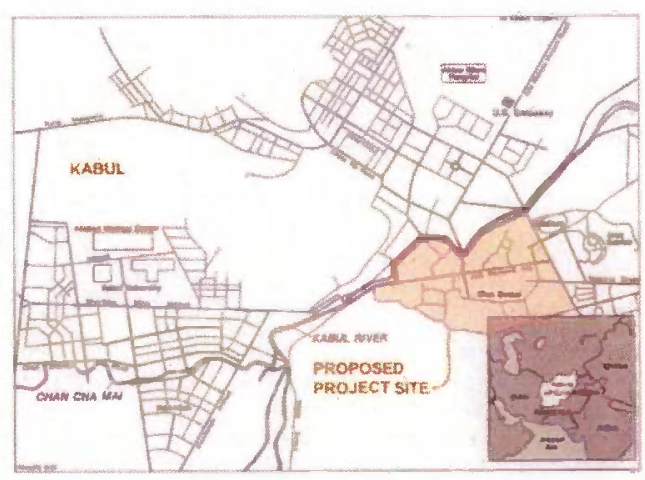

PROJECT LOCATION

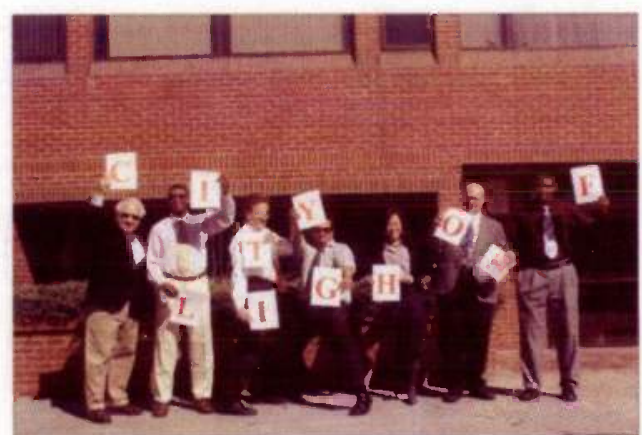

DESIGN TEAM:

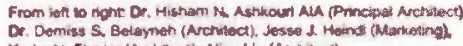

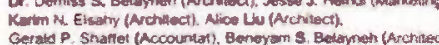


Kabul-City of Light

DEVELOPMENT PLAN

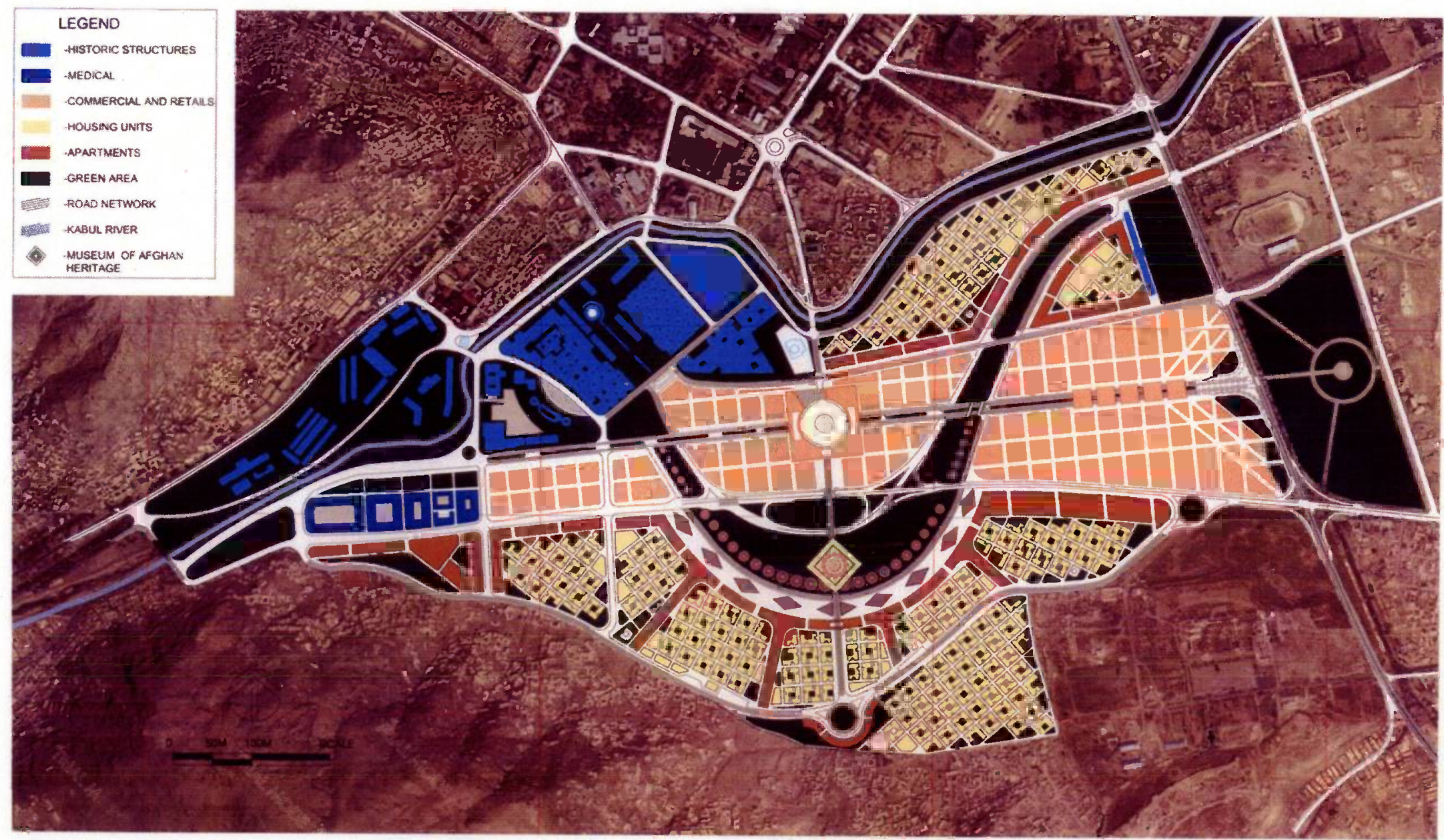




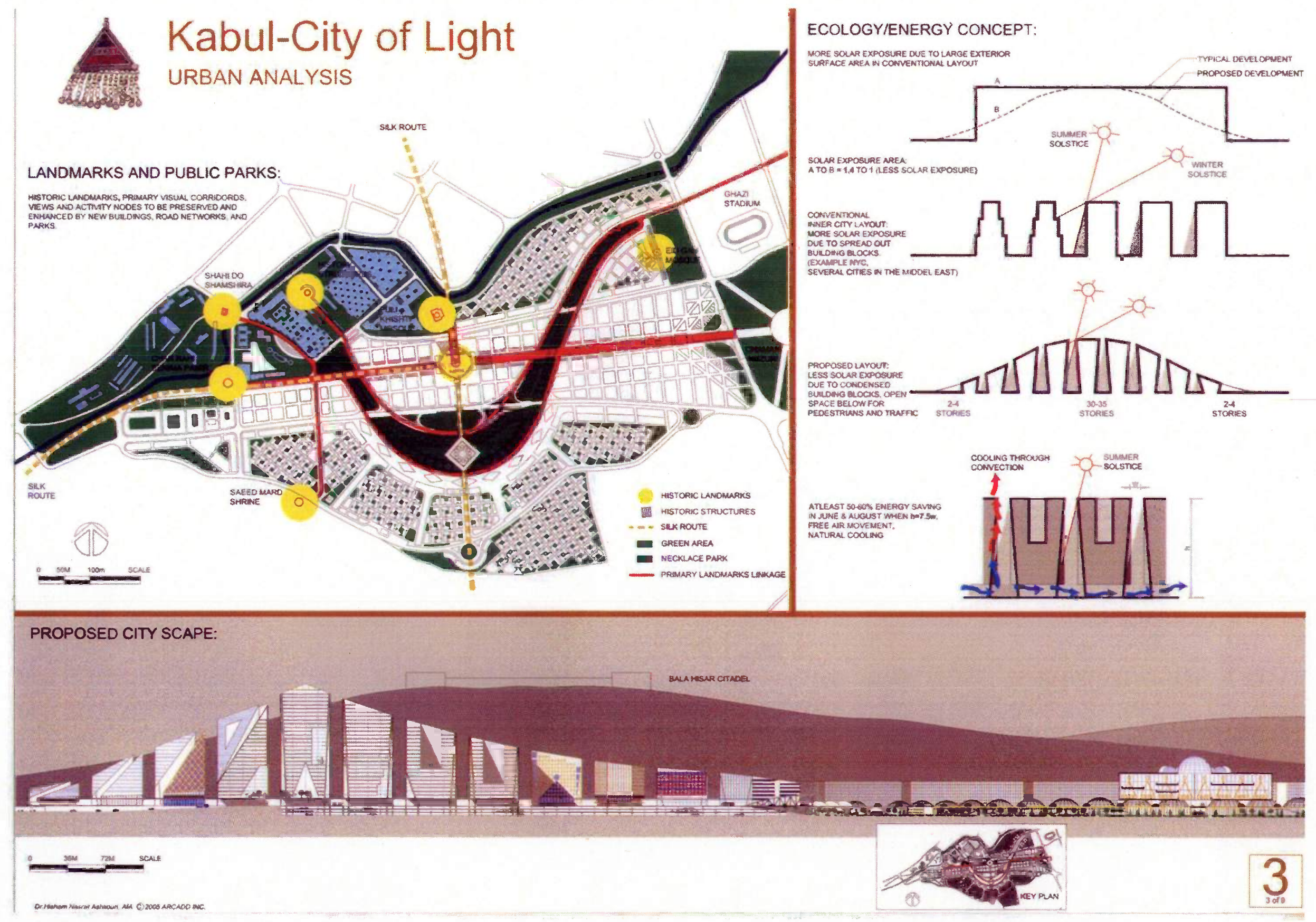


Kabul-City of Light

\section{EXISTING CONDITION}

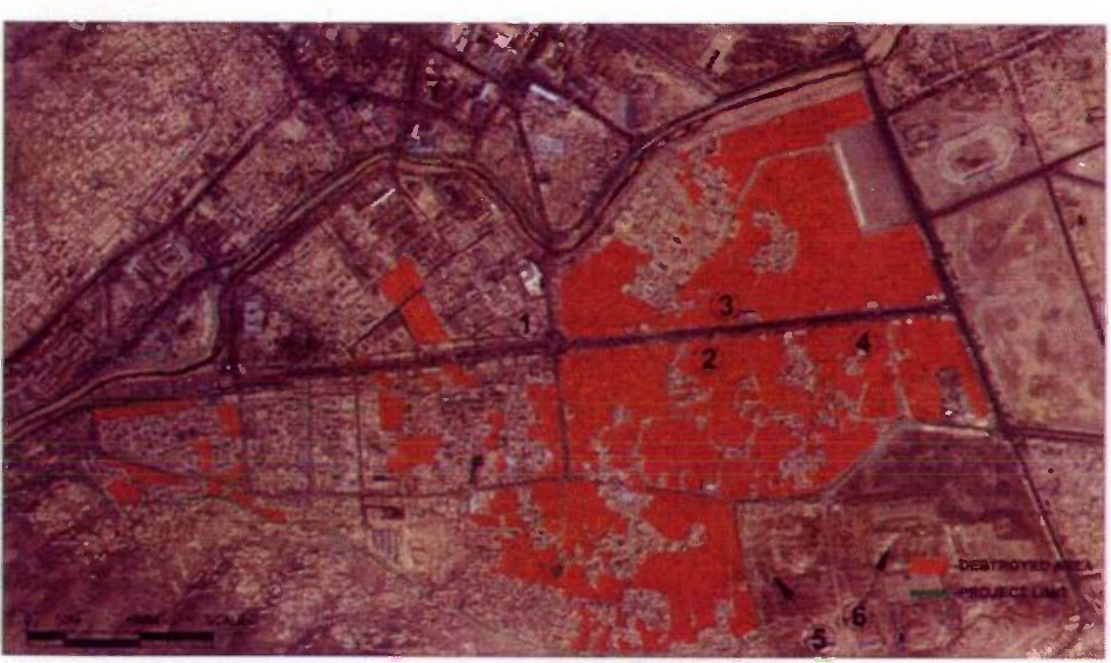

BOMBED AREAS OF THE SOUTHERN CITY OF KABUL
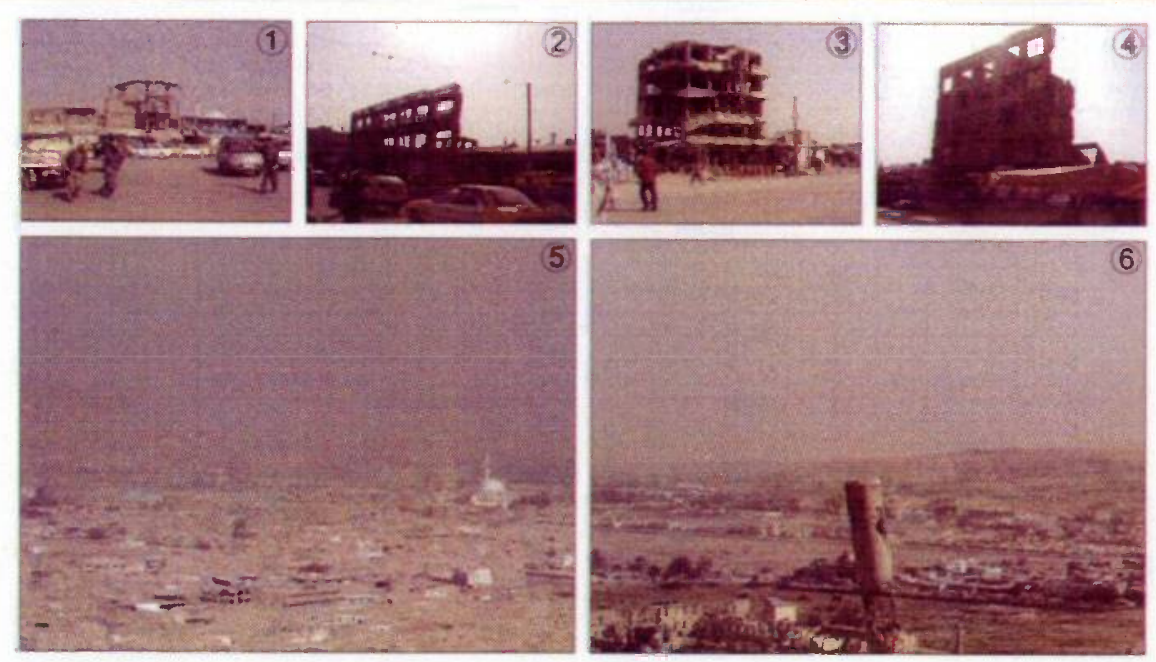

PHOTOS SHOWING RESULTS OF AFGHAN WARS
INFRASTRUCTURE AND ROAD

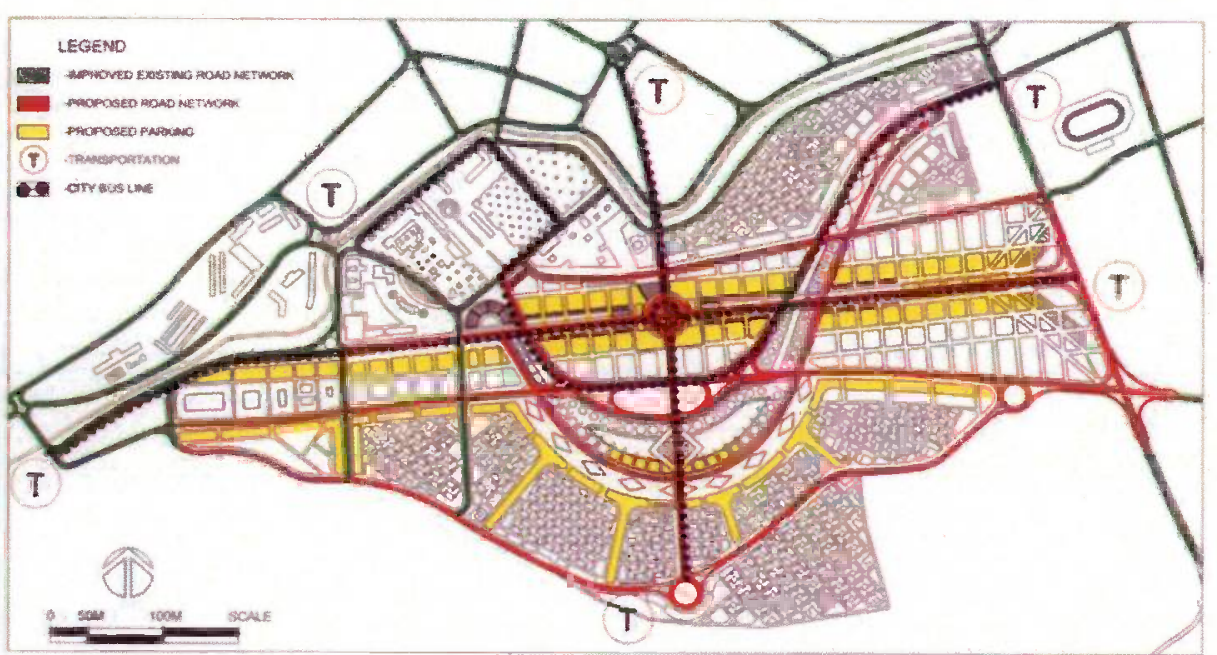

PROPOSED NEW ROAD NETWORK

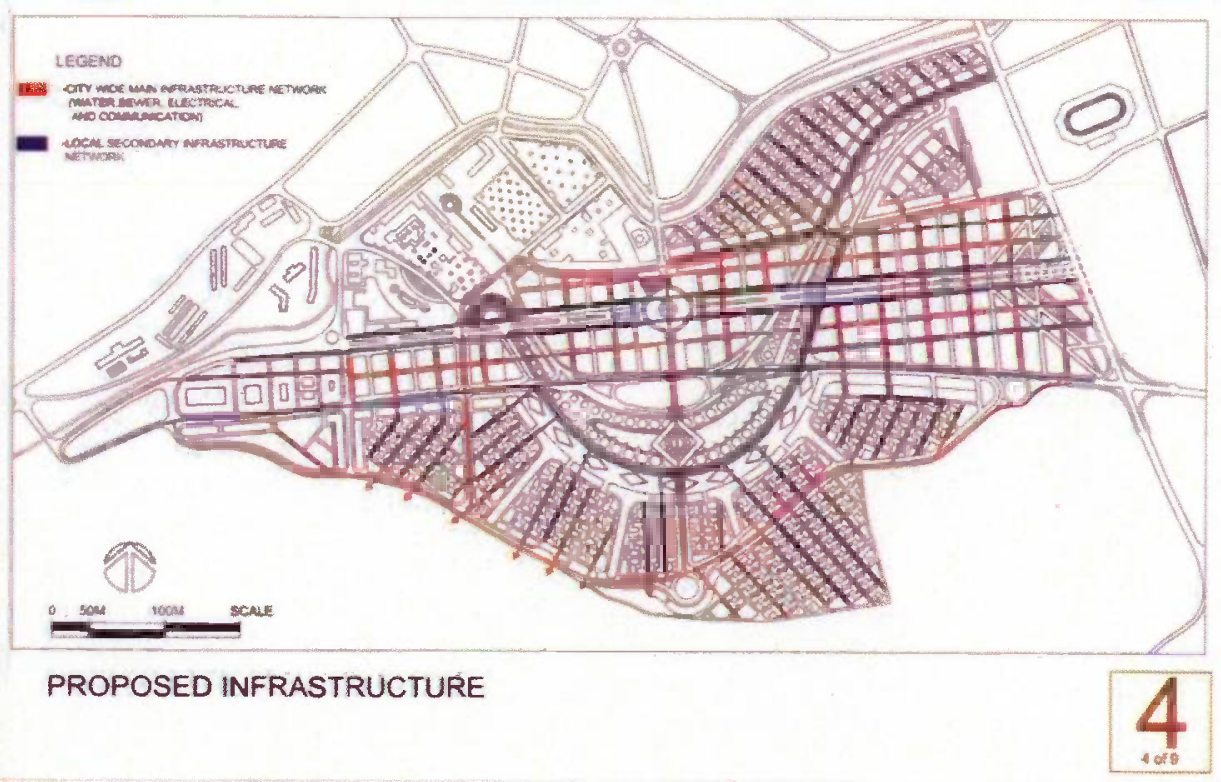


Kabul-City of Light HOUSING ANALYSIS

HOUSING TYPOLOGY:

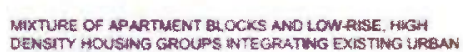
WNO SOCH TABAKS.

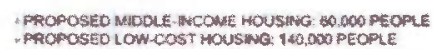

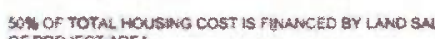

of $P$

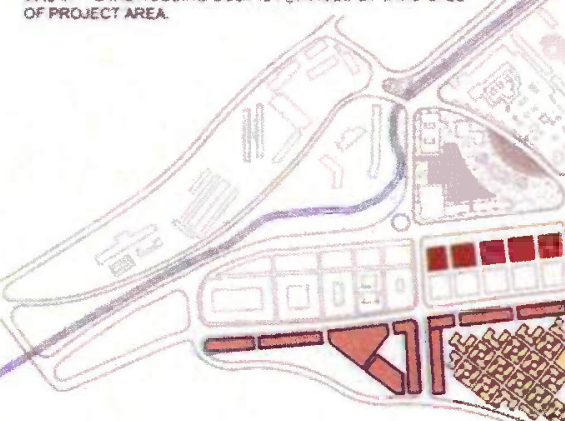

鄅

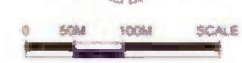

PLAN LAYOUT:

GROUPS OF HOUSANG UNATS CUUSTEAED AROLNO CONMON

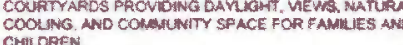

LOCAL CONTEXT:

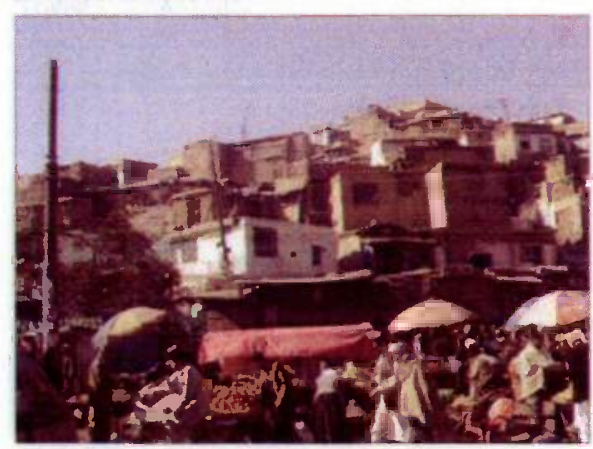

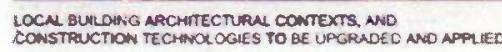

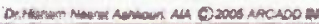

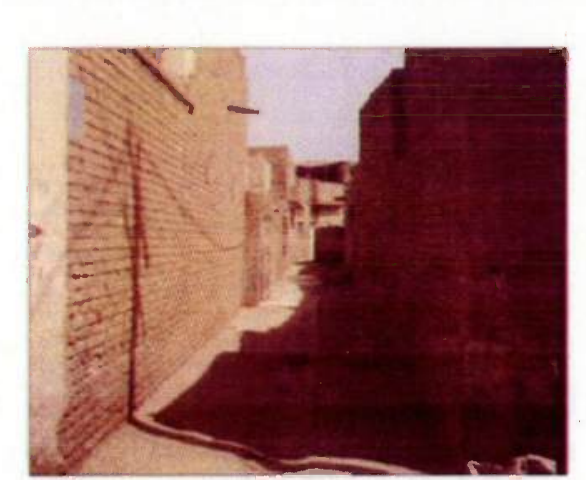

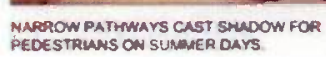

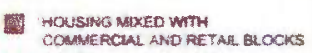

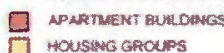

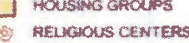

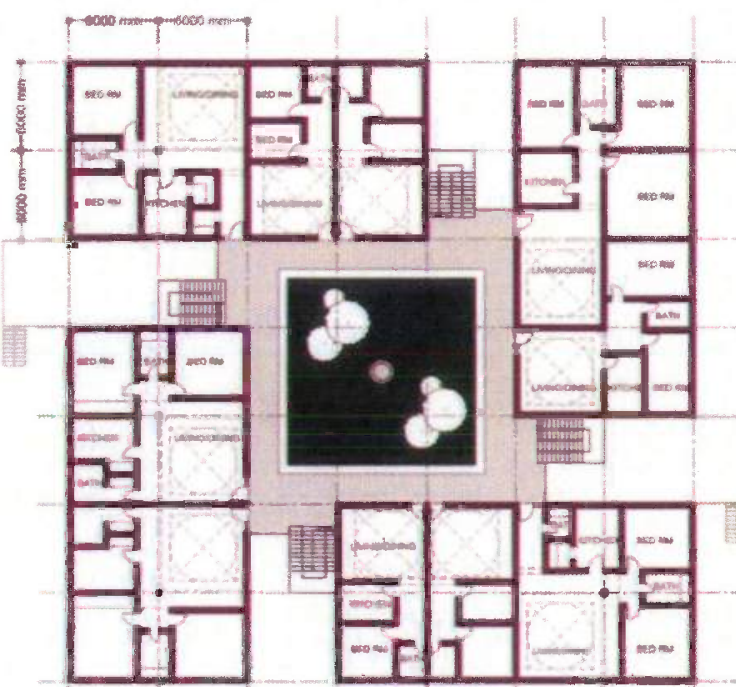

TECHNOLOGY:

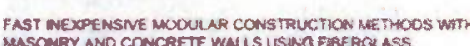

DOMES N NO VAULTS TO BE PRE + ARRICATEO

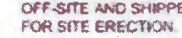

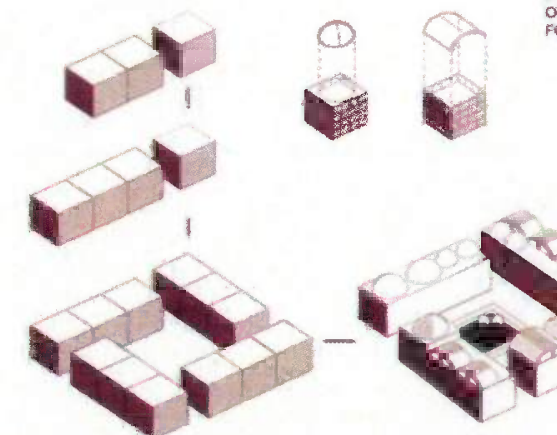


A Kabul-City of Light

ELEVATIONS AND SECTIONS
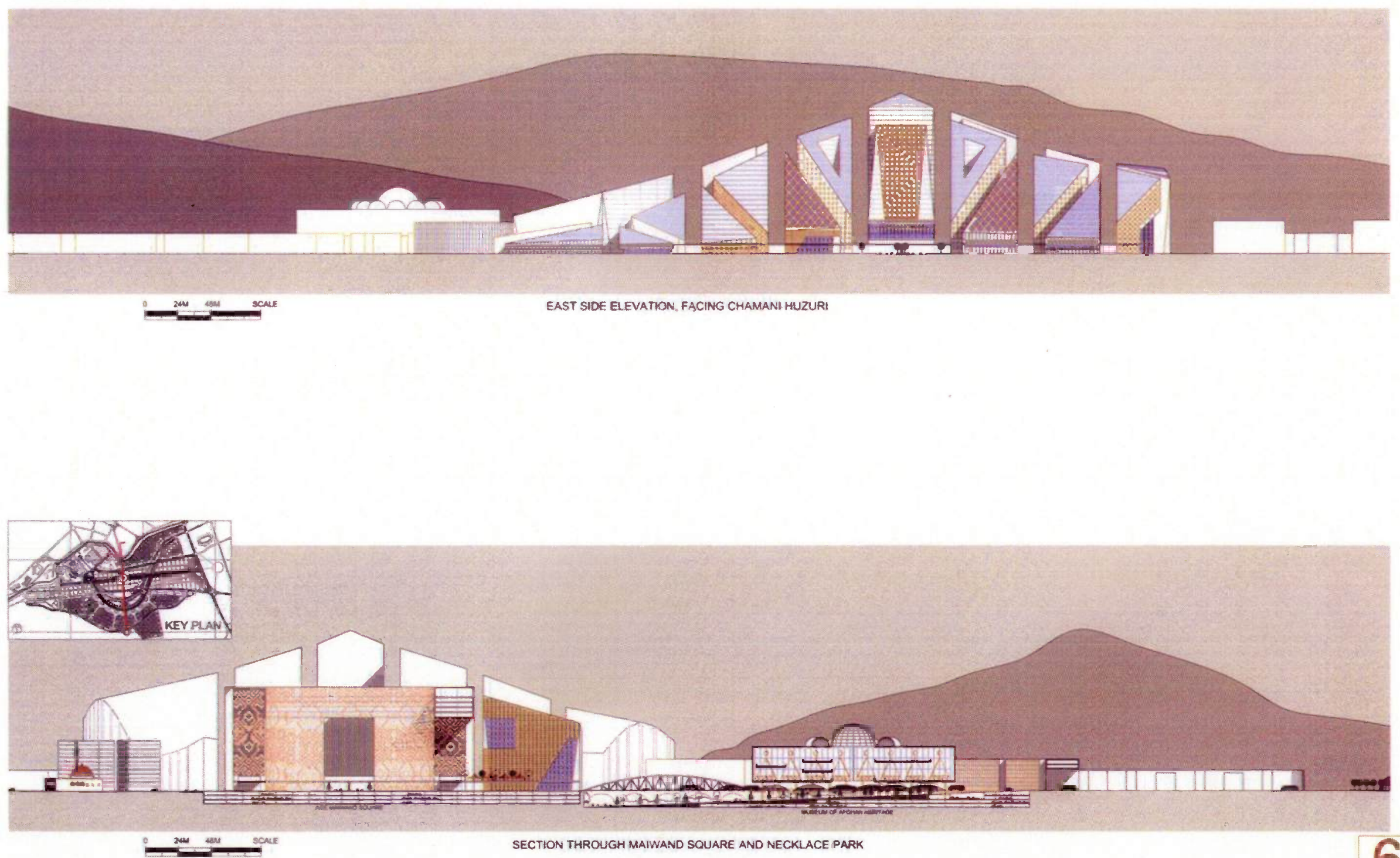
Kabul-City of Light

ELEVATIONS AND SECTIONS
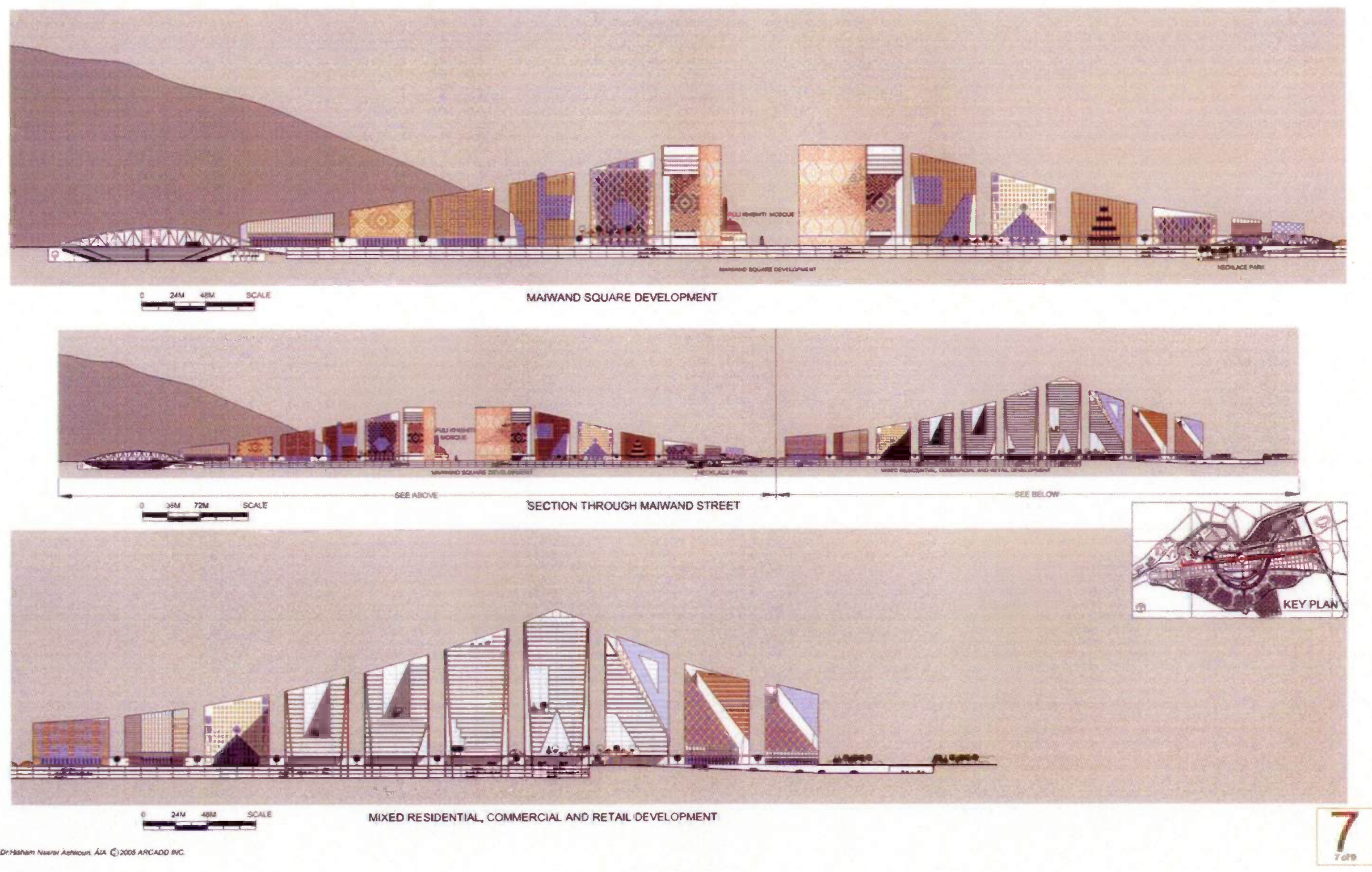


\section{Kabul-City of Light}

\section{PERSPECTIVES}

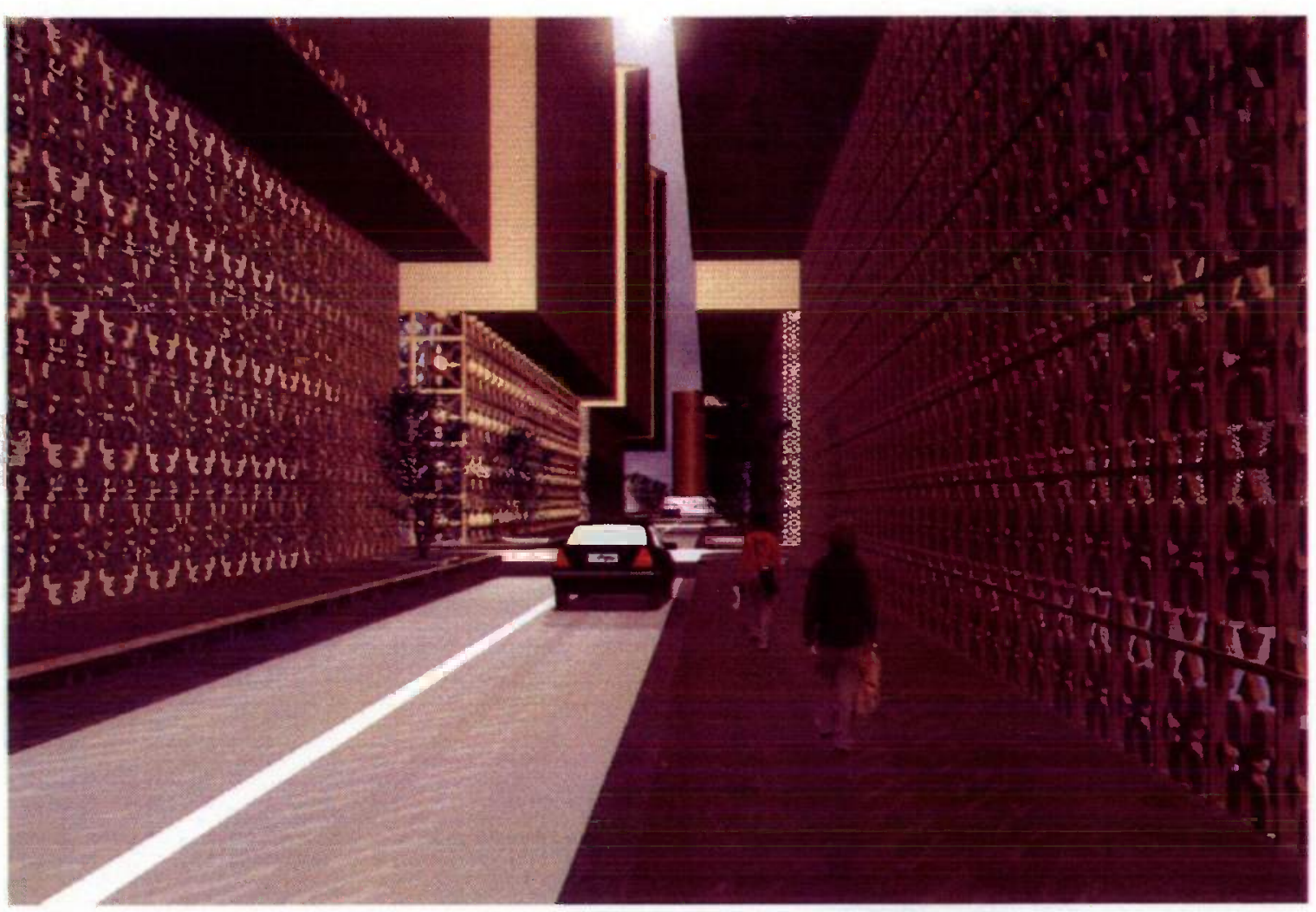

A, TYPICAL SHADING IN CONDENSED DEVELOPMENT

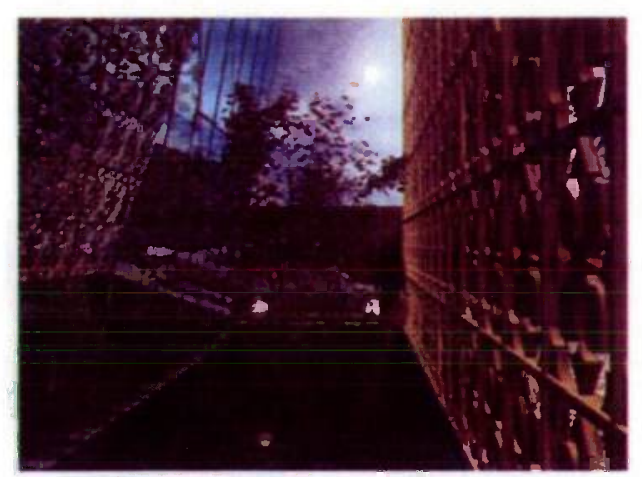

B - TYPICAL INTERIOR LOBBY OR PUBLIC SPACE

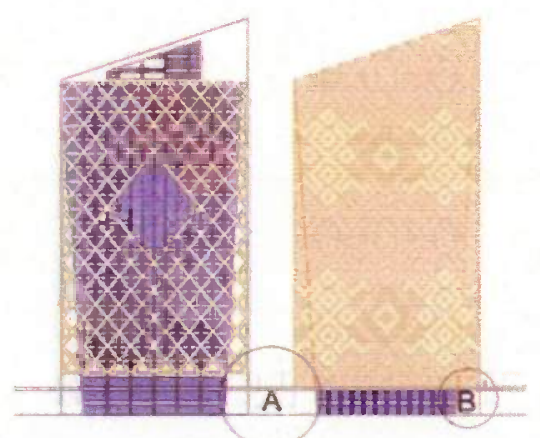

TYPICAL CONDENSED BUILDING AND STREET SECTION 


\section{Kabul-City of Light}
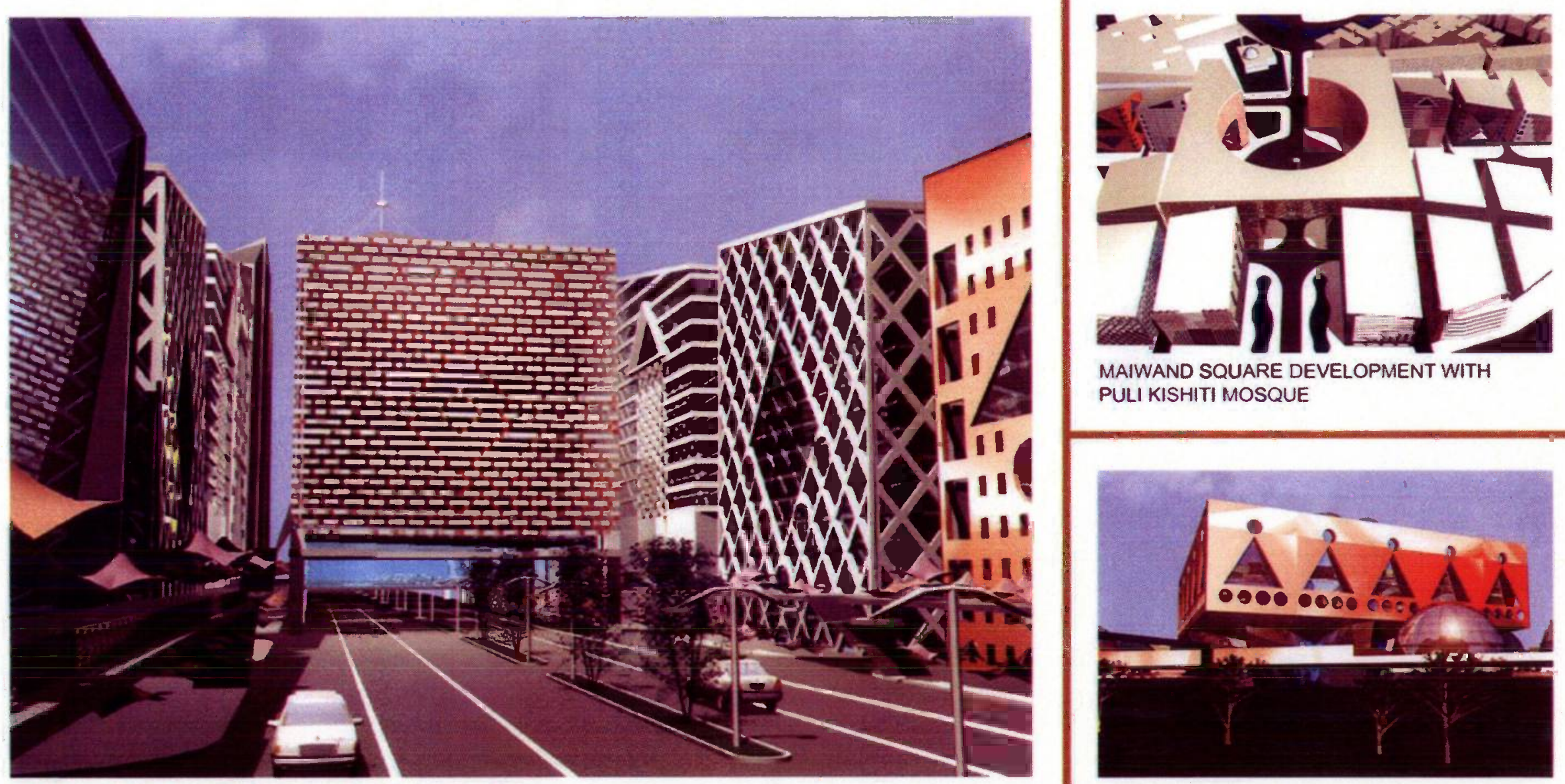

MAIWAND SQUARE DEVELOPMENT WITH PULI KISHITI MOSQUE

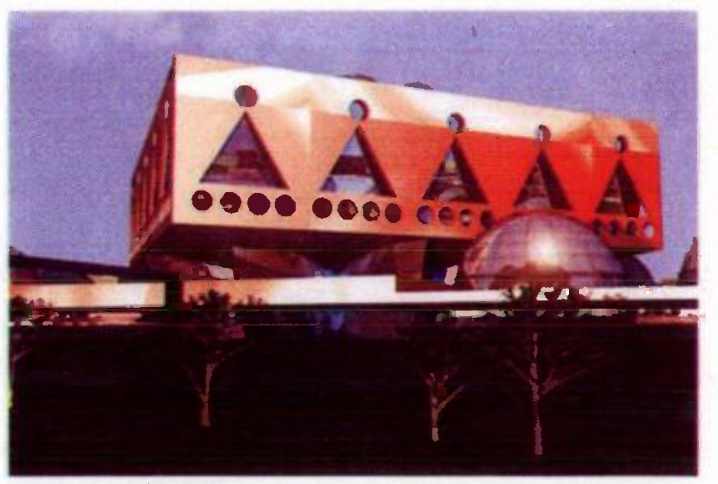

MAIWAND STREET COMMERCIAL, RETAIL, HOTEL AND HOUSING DEVELOPMENT

MUSEUM OF AFGHAN NATIONAL HERITAGE 


\section{Kabul: City of Light Development Private Sector}

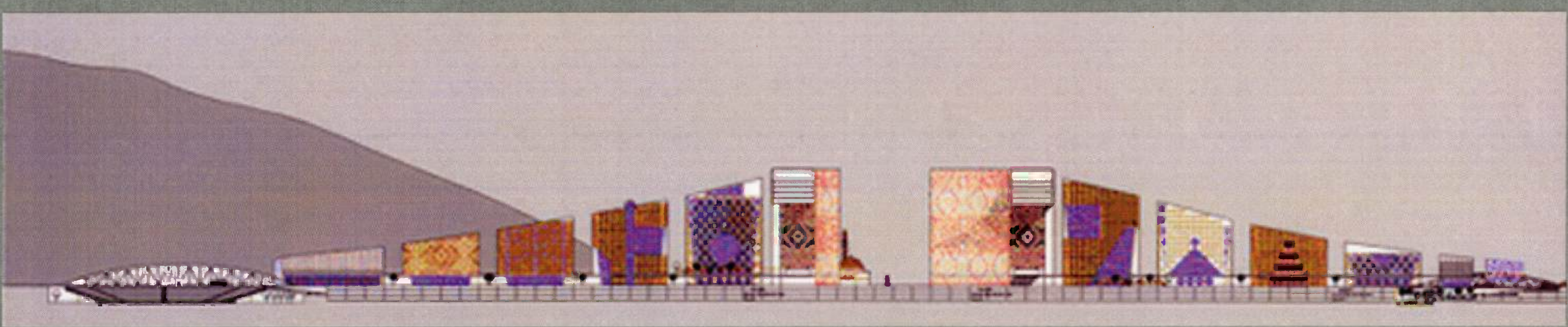

\section{A Vision of $21^{\text {st }}$ Century Kabul}




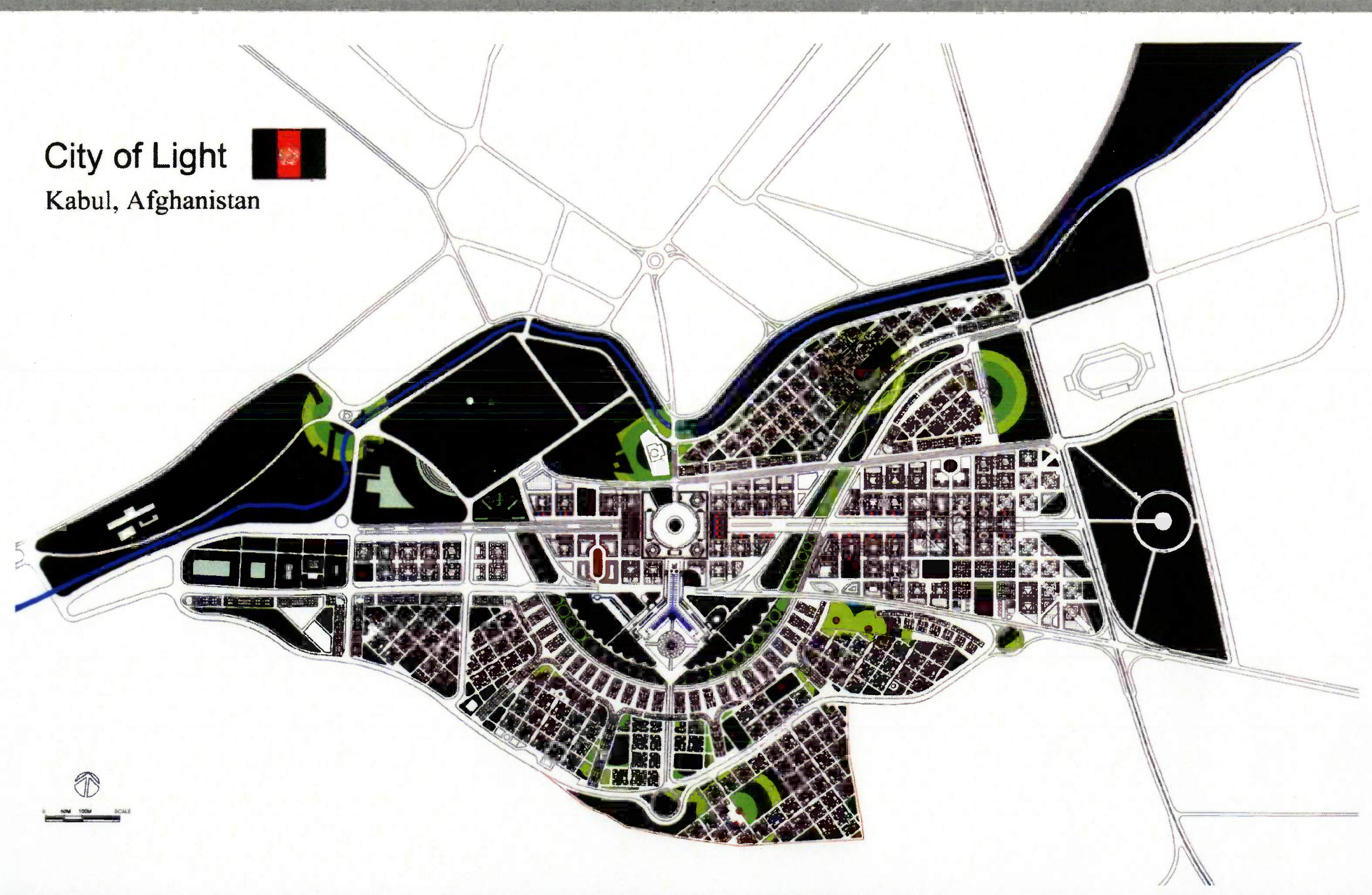




\section{Goals and Objectives}

The entire development is to be driven by the private sector, including those investors from within Afghanistan and outside international agencies and interested investors.

- The development is to respect the local culture, Islamic traditions and to incorporate the local Islamic architecture of mosques and shrines in Kabul for rehabilitation of such structures.

- The development will seek Afghan engineers, local workers and craftsmen, and will encourage local employment and training, resulting in reduction of poverty. The developers will include requirements for reasonable local participation in the contracting process. This plan projects the creation of 252,000 jobs during construction, and over $1,000,000$ jobs generated at the end of the development.

- The development will require new subsurface infrastructure, including new sanitary water networks and treatment facilities, a fresh water distribution and conservation network, a new electrical grid using self generating sources of electricity, and information technology systems.

The surface infrastructure networks including the development of new roadways and bridges over the Kabul River with proper pedestrian and vehicular traffic design and parking. These roadways shall incorporate new up-to-date street lighting and comfort (bathroom) stations. 


\section{Goals and Objectives}

- The development of a public park system, "Necklace Park", that will link the most important shrines and mosques in the Old City limits and will provide for family recreation and picnicking, pedestrian movement, a place to house the National Museum for Afghan Heritage, the National Library and National Cultural Center, and open quiet green space in the middle of the City of Kabul.

- The development of a new public transit system, including mini and larger energy efficient buses that will eliminate congestion and provide alternative means of transportation to reduce pollution in downtown Kabul.

The development will also focus on an overall improvement in the standards of living, family income and will allow for self-initiated growth and development, including social and psychological improvements for the community as a whole and for the families and individuals living within the Old City of Kabul.

- The planning of this development, although it entails review of the Master Plan of the City of Kabul, is not a master plan document, but rather a well planned individual mixed-use development made up of several urban nodes.

The design will generate public open space along major avenues and streets, which will become the grounds for open markets where current economic activities can be transformed into a $21^{\text {st }}$ century development, where new businesses and entrepreneurships can grow and develop in Kabul. 


\section{Goals and Objectives}

- The development will generate a new tax base for the City of Kabul that will help the City to rebuild some of its road network, infrastructure and its public services programs.

- $10 \%$ of the profit to be made from these developments will create an endowment to be used towards funding seed money for local investments in home repairs, upgrades and commercial local spaces. ARCADD will generate a plan for this reinvestment to occur with the consultation of the Afghan Government.

- The implementation of this plan will include architecture, urban design, traffic, transportation and infrastructure engineering, landscape architecture, environmental psychology and social planning. It will also include finance development, marketing, and public relation efforts to encourage other investors from various parts of the world, especially the Middle East, to invest in the development.

- The development will use up-to-date standards, building codes, fires safety and handicapped access requirements.

- The development will create a new architectural character that will make Kabul uniquely identifiable among other international cities. 


\section{Role of the Country of Afghanistan and the Private Sector}

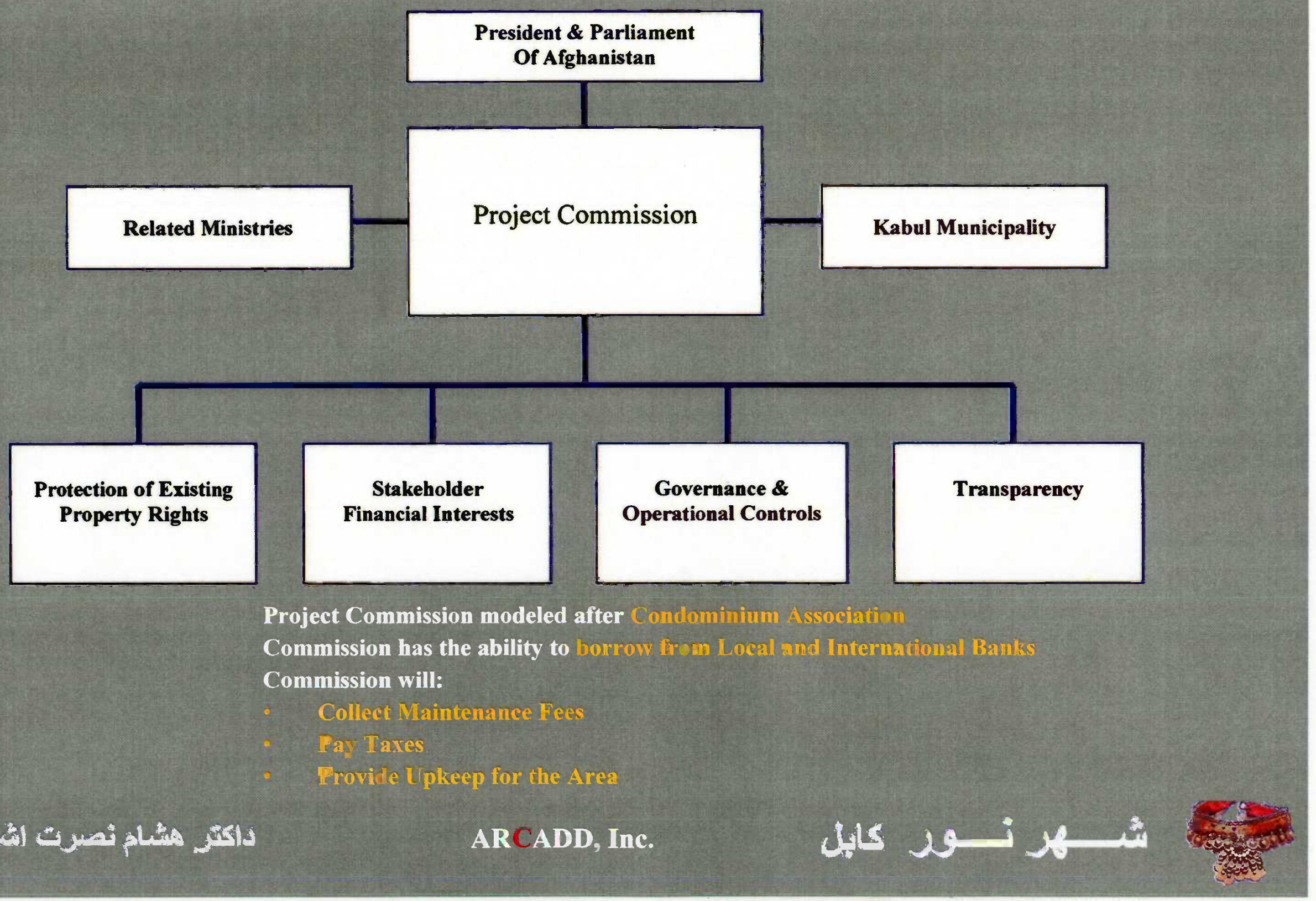


CITY OF LIGHT, Kabul, Afghanistan Cash-Flow Options 1 and 2

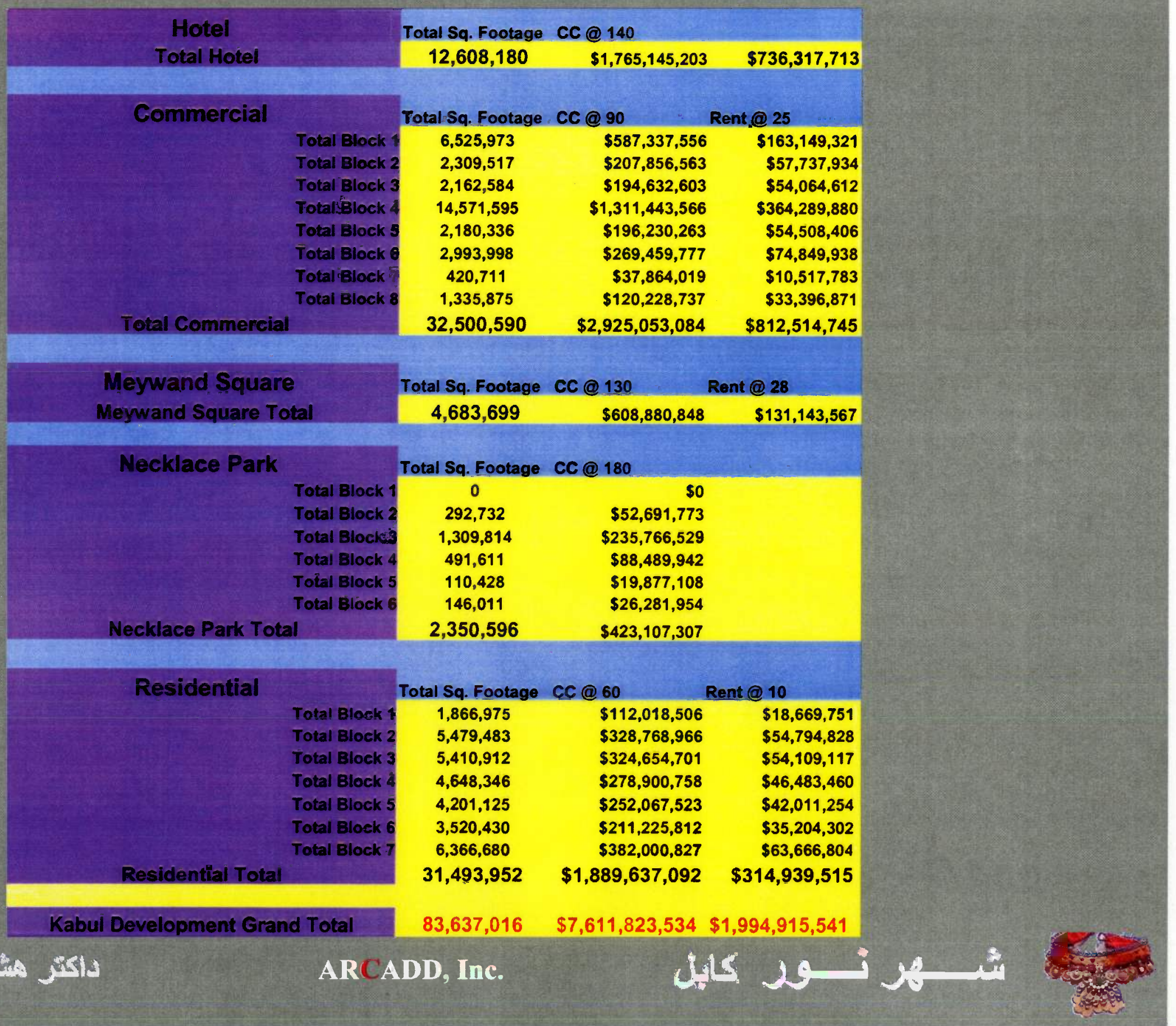


Price includes $\$ 2.0$ Billion for Infrastructure, Roads and Bridges

Mortgage payback @ $5.5 \%$ over 7 years

Mortgage payback @6.0\% over 7 years

Mortgage payback @ 6.5\% over 7 years

Monthly Mortgage

Annual Mortgage

Difference

$\begin{array}{lll}137,492,142 & 1,649,905,703 & 345,009.838\end{array}$

$139,716,266 \quad 1,676,595,197 \quad 318,320,344$

$\begin{array}{lll}148,378,104 & 1,780,537,248 & 214,378,293\end{array}$

Mortgage payback @ 5.5\% over 10 years

Mortgage payback@6.0\% over 10 years

Mortgage payback@6.5\% over 10 years $\begin{array}{lll}103,837,621 & 1,246,051,451 & 748,864,090\end{array}$

$106,180,047 \quad 1,274,160,565 \quad 720,754,976$

$\begin{array}{lll}108,552,320 \quad 1,302,627844 & 692,287,647\end{array}$

Mortgage payback @ $5.5 \%$ over 15 years

Mortgage payback@6.0\% over 15 years

Mortgage payback@6.5\% over 15 years

\begin{tabular}{lll}
\hline $78,178,303$ & $938,139,631$ & $1,056,775,910$ \\
\hline $80,706,497$ & $968,477,961$ & $1,026,437,581$ \\
\hline $83,278,212$ & $999,338,550$ & $995,576,991$ \\
\hline
\end{tabular}

Mortgage payback @ 5.5\% over 20 years

Mortgage payback@6.0\% over 20 years

Mortgage payback@6.5\% over 20 years

$65,816,854$ $789,802.243$ $1,205,113.298$

$68,519,492$ $822,233,904$ $1,172,681,637$ $71,277,090$ 855.325 .079 $1.139,590,462$ 


\section{Historic Preservation}

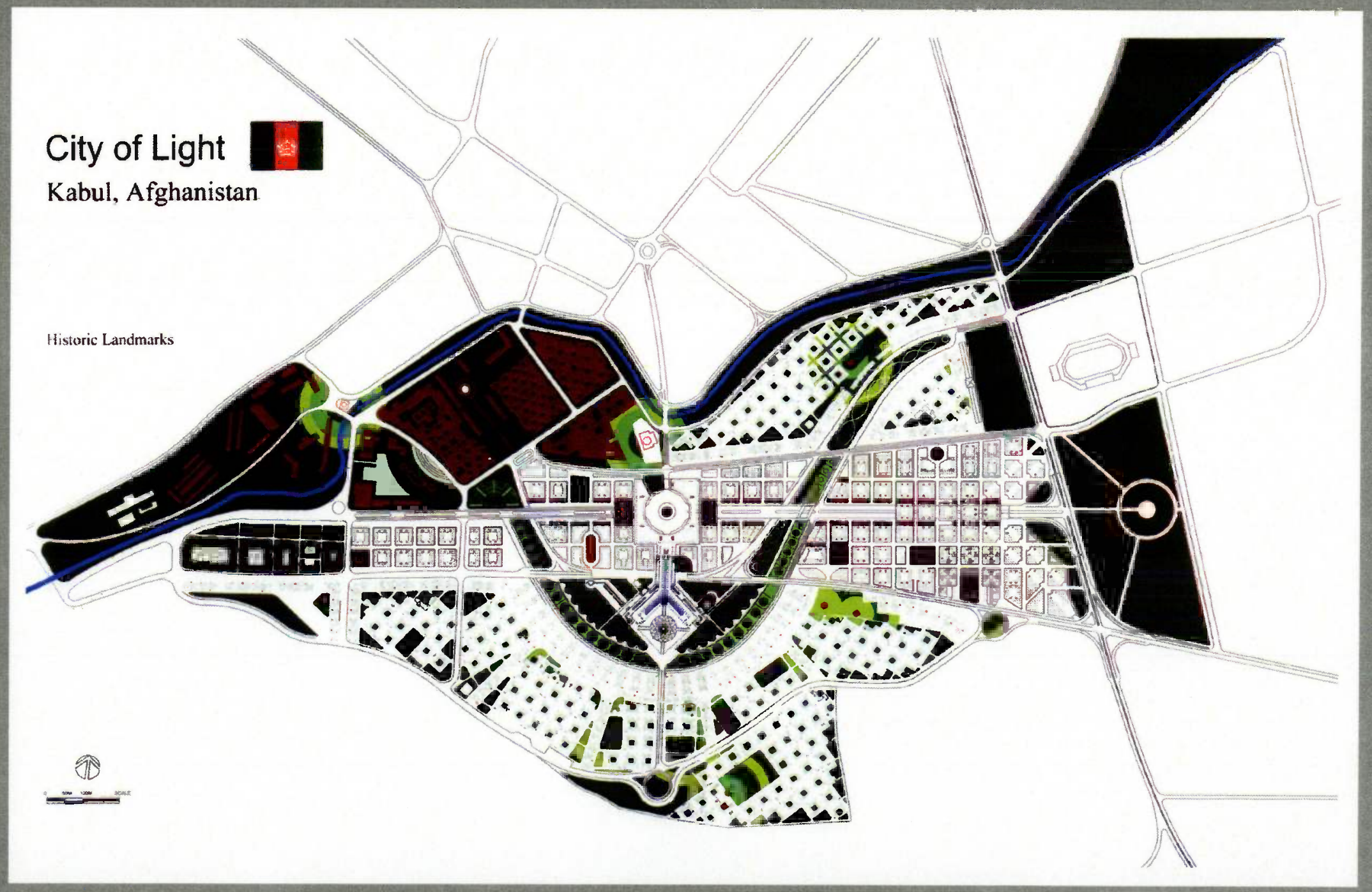

ARCADD, Inc.

4ts 


\section{Historic Preservation}

- Preservation of the Old City of Kabul including mosques, shrines, and significant centers will be a significant part of the City of Light Plan

- Preservation of Cultural and Historic identity of Afghanistan and its treasures

- City of Light will house the Afghan National Museum, Library and Cultural Center

- The Museum will be an active institution of learning and a new center of knowledge 


\section{Afghan National Museum}

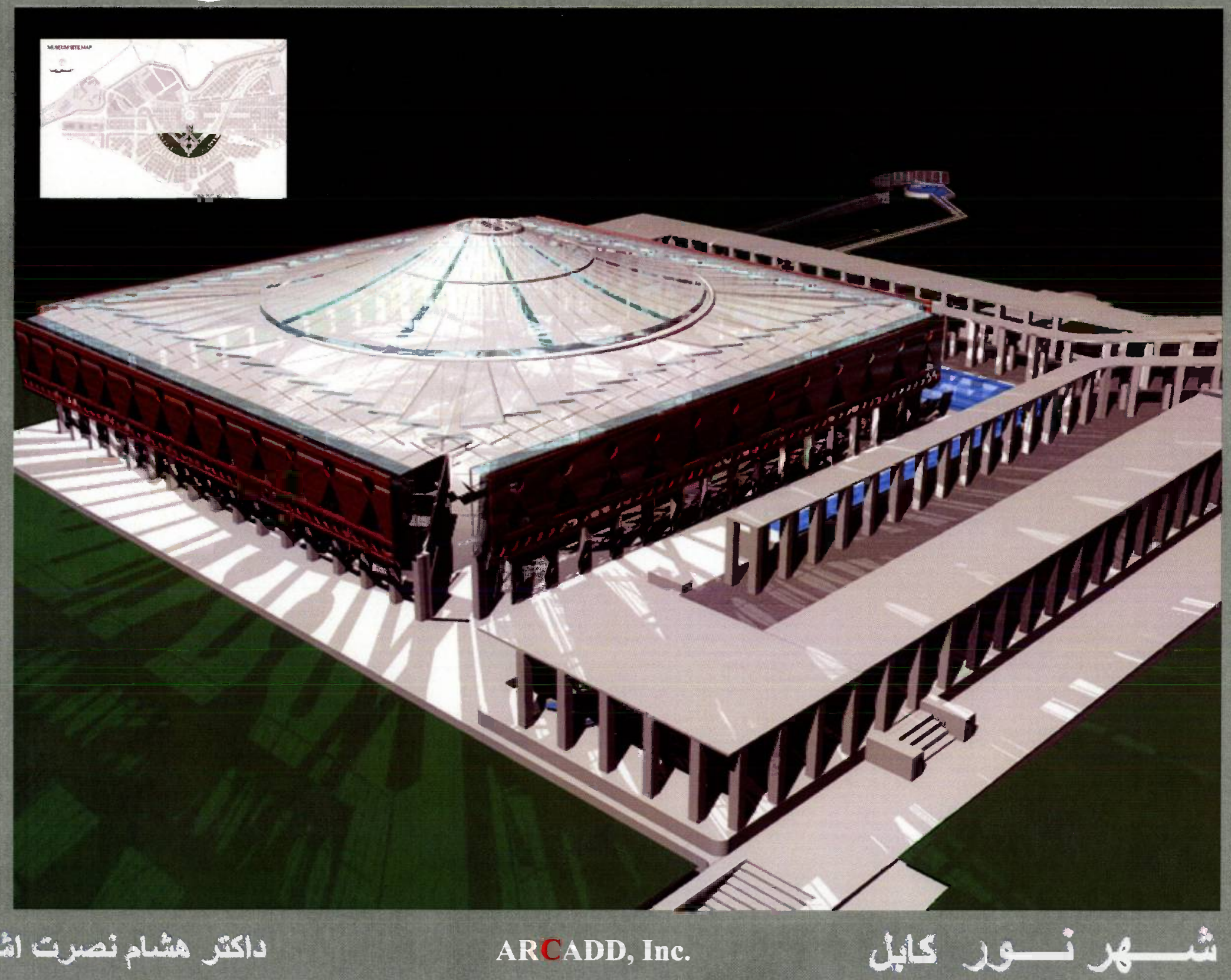

such syai pha gits

ARCADD, Inc.

ش 


\section{Housing Impact}

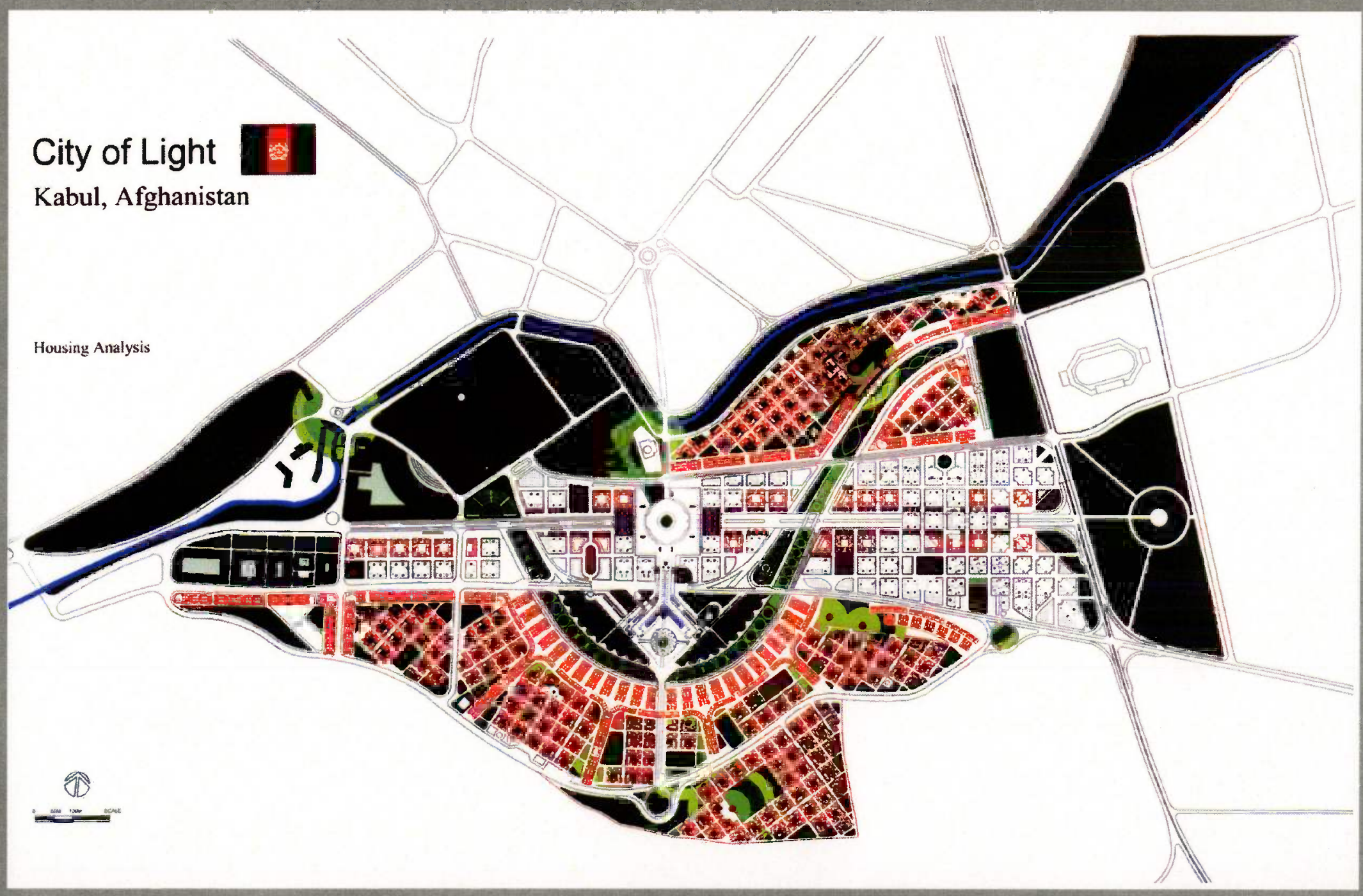




\section{Future of City of Light/Kabul as the}

\section{Central Asian Hub for New Business}

ELEVATIONS AND SECTIONS

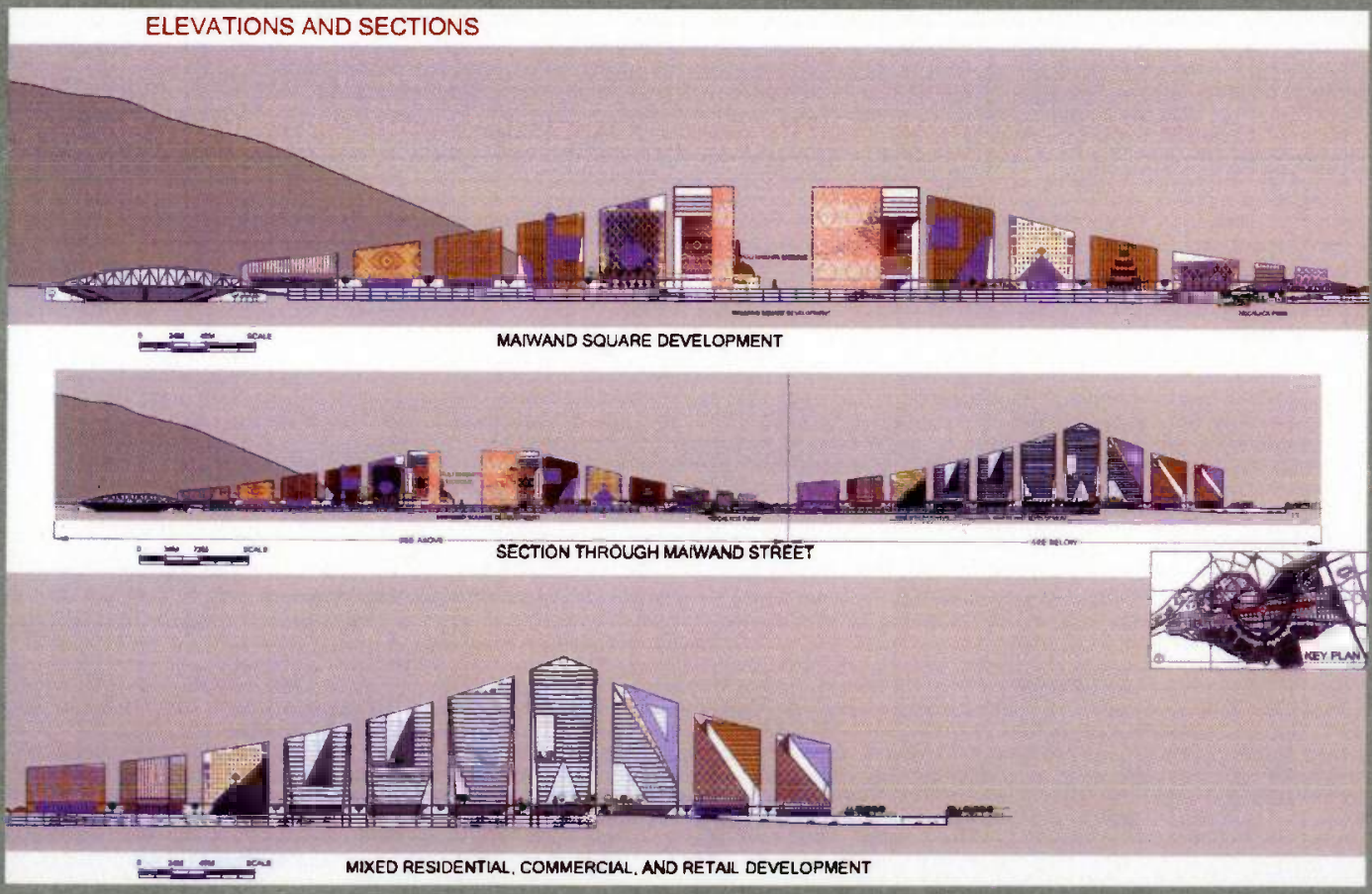

- Design of the new buildings in Kabul will allow local and foreign businesses to establish operational headquarters and offices in the City of Light area

- Home offices in countries such as Turkey, Iran, Uzbekistan, India, Japan, etc., will establish satellite offices in Afghanistan 


\section{Development of Modern Roadways, Bridges and}

\section{District Transportation System}

- New bus routes will be the method of transportation

- New paved road and bridges to be used

- Proper street lighting and traffic control to be implemented

- Will reduce both dust and fossil fuel pollution resulting from current poor road and

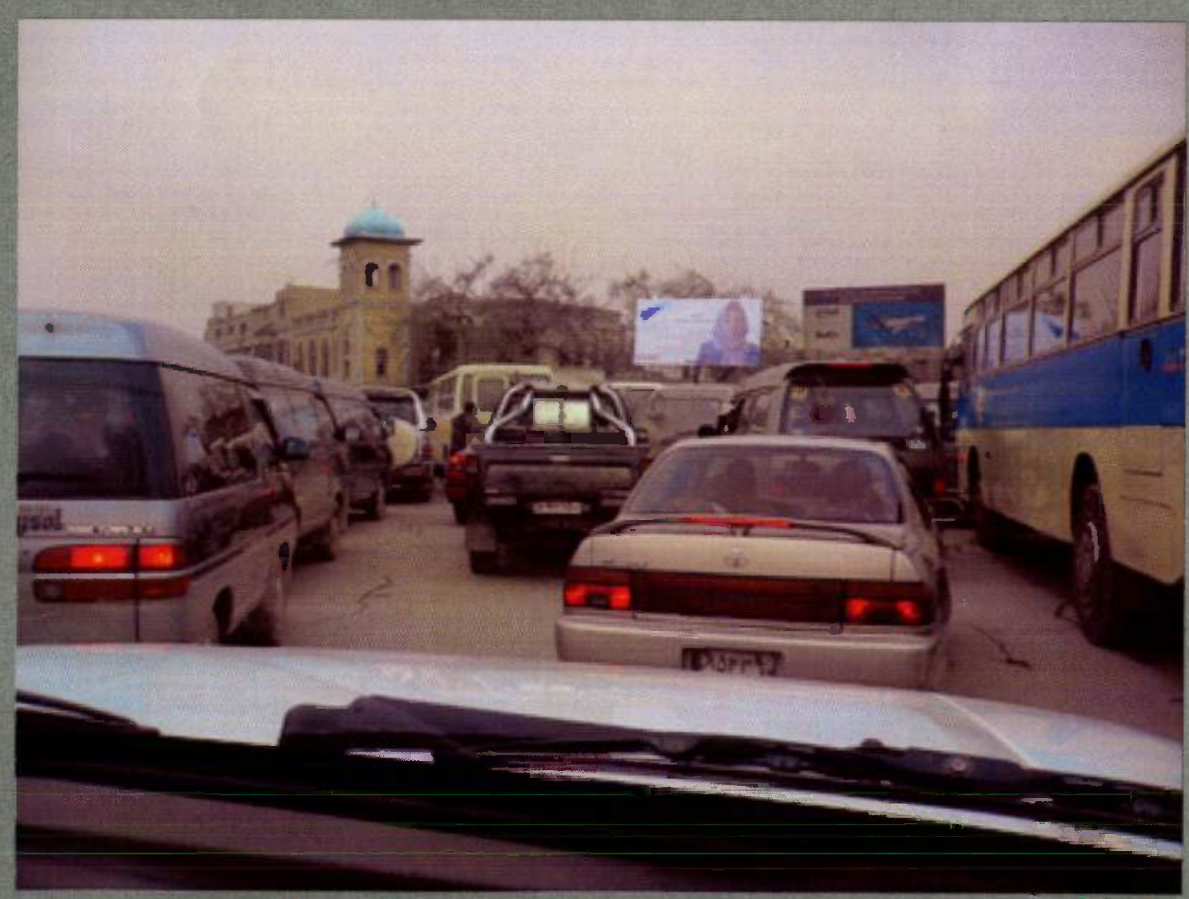
dense car utilization 


\section{Sense of Pride, Learning and Accomplishment}

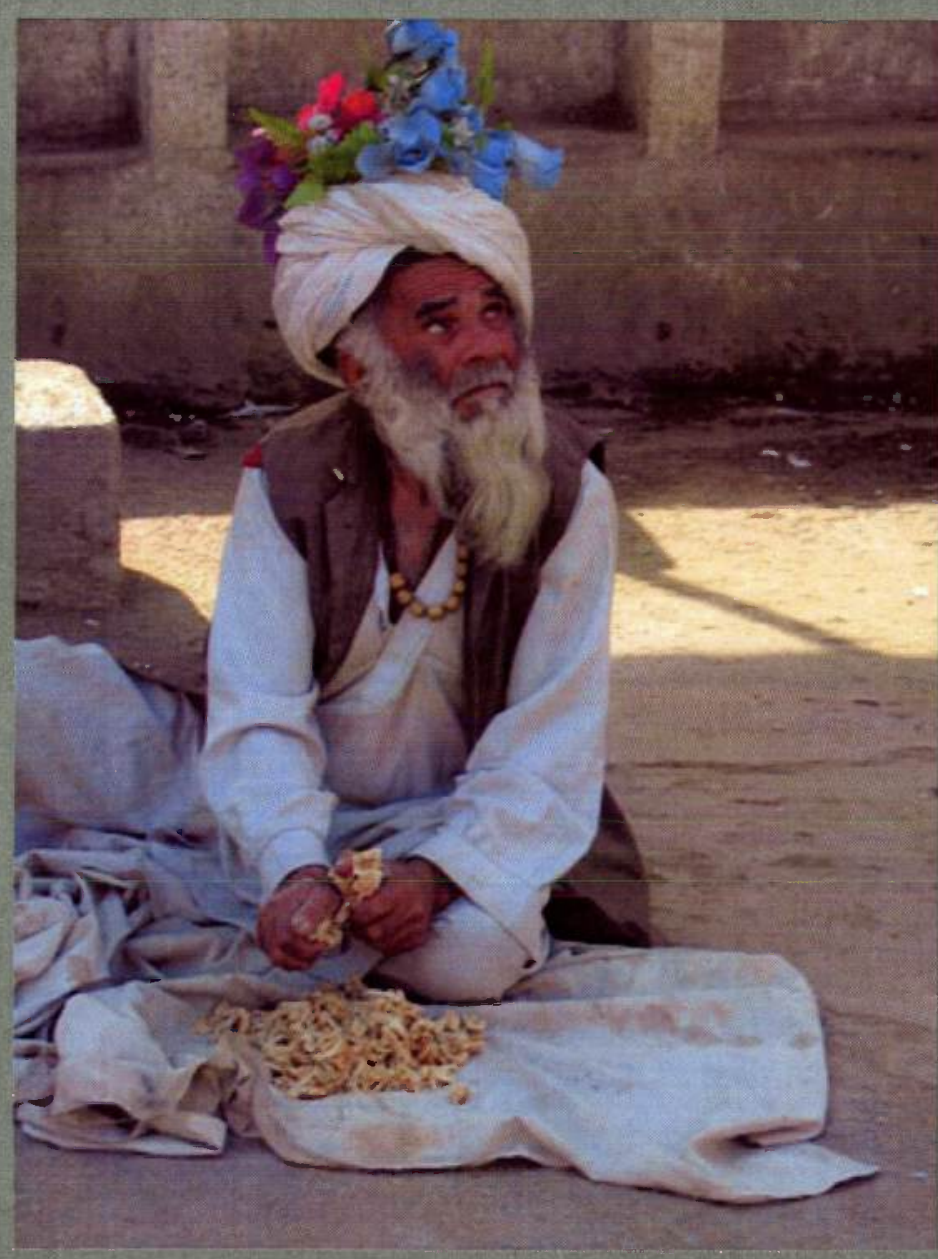

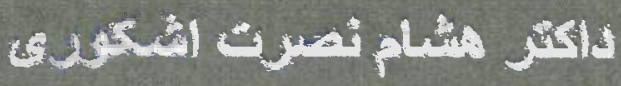

- Citizens of Kabul Empowerment

- Afghanistan in general, Sense of Democracy 